\title{
COOPER, Frederick. Citizenship, inequality and difference: Historical perspectives. Princeton \& Oxford: Princeton University Press, 2018.
}

Paulo Henrique Silveira Damião ${ }^{l}$

Publicado em 2018 pela Princeton University Press, Citizenship, Inequality and Difference, de Frederick Cooper, torna-se um importante ensaio para refletirmos a respeito da constituição e implantação da cidadania em diferentes temporalidades, contextos e espaços. Professor da University of New York e especialista em "colonialização", "descolonialização" e História africana, Cooper parte da crise humanitária imigratória contemporânea, resultado do colapso dos impérios na África e na Ásia, para fazer a necessária constatação de que cidadania não é sinônimo de igualdade, nem de justiça. $\mathrm{O}$ livro está estruturado em três capítulos: "Imperial citizenship from the Roman Republic to the Edict of Caracalla", "Citizenship and Empire - Europe and beyond" e "Empires, nations and citizenship in the twentieth", além de Introdução e Conclusão.

$\mathrm{Na}$ introdução do livro, o autor apresenta alguns dos problemas que envolvem o estudo da cidadania. Fica bastante claro que duas questões vão percorrer todas as suas páginas: os problemas em torno do próprio conceito de cidadania, identificado como abrangente, ambíguo e difuso demais para ser útil analiticamente, e o que significa ser cidadão em diferentes espaços e experiências, expressão do sentimento de pertencimento, dos direitos e das obrigações. Com isso em vista, questiona-se: Qual é a relação entre o fato do

\footnotetext{
1 Doutorando do Programa de Pós-Graduação em História da Universidade Estadual de Campinas (UNICAMP). É Licenciado, Bacharel e Mestre em História pela Universidade Federal de Juiz de Fora (UFJF) e vinculado ao Centro de Pesquisa em História Social da Cultura (CECULT), do Instituto de Filosofia e Ciências Humanas da UNICAMP. Bolsista do Conselho Nacional de Desenvolvimento Científico e Tecnológico (CNPq). E-mail: paulohenriquesd@hotmail.com
} 
pertencimento a uma unidade política e a possibilidade de se fazer reivindicações?

Cooper sugere que a cidadania não tem sido simplesmente um status comum que pressupõe a equivalência dos cidadãos, mas uma estrutura para debater e lutar pela relação da pertença política com as diferenças religiosas, linguísticas e culturais. Assim, cidadania implica, para o autor, não só ter o direito de ter direitos, mas pertencer a algum tipo de coletividade política e ter o direito de poder reivindicar direitos. Frederick Cooper defende que há variados tipos de unidades políticas nas quais a cidadania poderia ser exercida e contestada, incluindo cidades, impérios, federações e comunidades culturalmente definidas, bem como Estados-Nações, em contraponto a uma literatura que procurou cingir o exercício da cidadania às fronteiras de um país.

Para complexificar seus argumentos, Cooper apresenta diferentes formas em que a cidadania poderia ser exercida e contestada. A definição de "cidadania minimalista" a compreende como uma instituição que media os direitos entre os sujeitos políticos e a política na qual esses sujeitos pertencem. Já a "maximalista" insiste que cidadania necessariamente implica na regra da lei, na participação total nas decisões políticas e na igualdade entre todos os cidadãos. Há também a cidadania do tipo "vertical”, que se expressa através da existência de um tipo de relação entre um seguidor e um "líder" - que pode ser um ancião, um rei ou um presidente, e a do tipo "horizontal", na qual o cidadão é membro e partícipe de uma comunidade política.

O primeiro capítulo, "Imperial citizenship from the Roman Republic to the Edict of Caracalla", cumpre, dentro da proposta argumentativa do autor, uma dupla função. Por um lado, procura demonstrar que o exercício da cidadania tem uma história que começa antes da criação dos Estados-Nações, ou seja, a cidadania já era um importante conceito para os impérios. Por outro, apresenta uma ideia de cidadania que é constituída a partir da diferença, visto que, dentro do Império, ser cidadão implicava participar de uma comunidade política, na expectativa de que a unidade e seus líderes fornecessem proteção contra pessoas de fora e criassem instituições judiciais que buscariam regular a 
relação entre seus membros. Assim, a cidadania imperial, ao mesmo tempo que era inclusiva, devido à incorporação de novos cidadãos, excluía tantos outros pela diferença e pela desigualdade, ao negar, por exemplo, direitos às mulheres.

No segundo capítulo, "Citizenship and Empire - Europe and beyond", Frederick Cooper adentra o universo dos impérios a fim de validar a existência de relações pessoais em diferentes lugares com diferentes línguas, orientações culturais e conexões sociais, uma construção usada para fazer reivindicações que poderia ser inclusiva ou excludente, lócus da cidadania. Neste capítulo, o surgimento do capitalismo e da declaração dos direitos do homem na França exerce papel fundamental dentro do raciocínio do autor, pois vai realizar uma alteração na definição do que é cidadania.

Ao abordar a experiência e o exercício da cidadania em impérios que estavam além da Europa e em contextos anteriores a 1789, Cooper se distancia, assim, de uma literatura que identificava aquele momento como o da criação da cidadania, afastando-se de definições mais eurocêntricas. A construção do sentimento de igualdade e de valores universais, pós-1789, vai potencializar a definição maximalista de cidadania, dando contornos mais homogêneos a ela. A cidadania ao longo do século XIX se coloca como uma estrutura de luta, para se debater sobre quem poderia desfrutá-la, ou seja, sobre quem poderia ser incluído ou excluído.

Essas questões são melhor discutidas no capítulo 3, "Empires, nations and citizenship in the twentieth", no qual o processo histórico de transformação dos antigos impérios em nações, a partir da segunda metade do século XX, acabou, segundo Cooper, obscurecendo a variedade de transformações da cidadania ao longo daquele século. $\mathrm{O}$ autor retoma o entendimento de que cidadania é uma estrutura na qual pessoas articulam seus sensos de comunidade, com diferentes graus de sentimentos de exclusão e inclusão.

As experiências de transição se mostraram extremamente diferentes e ricas para o conceito de cidadania, de forma que Cooper se atenta para uma cidadania que está além das fronteiras nacionais, ou seja, que reúne pessoas de diversos países, tal como a União Europeia, onde essas pessoas têm direito ao 
trabalho e à educação. Ao mesmo tempo, Cooper também apresenta uma cidadania diferenciada por grupos ou multinacional, que seguia a lógica anterior, mas ocorria dentro do Estado, o que permitia ao cidadão exercer sua cidadania de diferentes formas. Essas experiências silenciadas, acabaram por gerar, na contemporaneidade, os diversos conflitos enfrentados por imigrantes e movimentos sociais em geral, pelo fato de terem, nos países que chegam, direitos básicos negados.

Em resumo, as diferenças e desigualdades fazem parte do jogo da cidadania. Tendo o colapso dos impérios coloniais como ponto de partida, o autor chama atenção para a existência de uma tensão entre homogeneidade e diversidade, algo que potencializa sua crítica à simetria entre cidadania e igualdade. Ao reconhecer as diferenças (religiosas, culturais, de gênero, raça, etc.) como partes fundamentais para se exercer a cidadania, o autor apresenta um conceito de cidadania amplo, no qual, a priori, não pode ser mobilizado como um modelo pré-determinado. Dentro desse conceito mais amplo, Cooper apresenta diferentes formas em que a cidadania foi reivindicada ou contestada, a exemplo da cidadania de tipo horizontal ou vertical e das suas definições minimalista e maximalista. No entanto, o autor reconhece que há duas características que são intrínsecas a ela: o pertencimento a uma entidade política e o direito de reivindicar direitos. Em suas certeiras palavras, "cidadania é o direito de ter direitos - ou, melhor, o direito de reclamar direitos" (COOPER, 2018: 10).

Recebido em: 04 de fevereiro de 2020

Aceito em: 04 de julho de 2020 